\title{
Helgen i grenseland. Arven fra Trifon av Petsjenga
}

\author{
Caroline Serck-Hanssen \\ Stamsund: Orkana 2017 \\ 319 sidor. ISBN 9788281043053
}

Recenserad av Per-Arne Bodin [Professor emeritus i slaviska språk, Stockholms universitet,pab@slav.su.se]

Längst upp på Nordkalotten sammanstrålar fyra länder, två kristna kyrkor, tre olika ortodoxa kyrkliga jurisdiktioner och mer än en handfull olika folk. Caroline Serck-Hanssen fokuserar i sin bok Helgen $i$ Grenseland på en särskild aspekt på detta område, den ortodoxa traditionen i Petjenga (Petsamo) med omgivningar. Två munkar, Trifon och Feodorit, etablerade ortodoxin i trakten och kristnade skoltsamerna på 1500-talet. Det kloster som Trifon byggde brändes ner av finnarna (eller om man så vill svenskarna) 1589. Det flyttades och återetablerades flera gånger. I slutet av 1800-talet blomstrade det och blev både ett pilgrims- och turistmål. Efter första världskriget blev en del av området finskt med namnet Petsamo. Andra världskriget gick hårt åt trakten och efter kriget blev Petsamo sovjetiskt territorium. Efter Sovjetunionens fall har ortodoxin och klostret återetablerats och ortodoxin finns också närvarande på den norska sidan. Den gemensamma ortodoxa traditionen och arvet från Trifon har idag blivit gemensamhetsskapande element i denna trakt. Den nya vägtunneln som förkortar vägen mellan Nordnorge och Ryssland har symtomatiskt nog fått namnet Trifontunneln.

Helgen $i$ Grenseland presenterar denna långa och fascinerande och understundom våldsamma historia. Man hade kunnat förvänta sig att den första tiden skulle vara höljd i dunkel, men Serck-Hanssen visar att den blev mycket väl dokumenterad i holländska, tyska och ryska källor redan på 1500-talet. Området var rikt och klostret och lokalbefolkningen handlade med päls, fisk, renkött och hjortron. Det som en utomstående betraktare skulle uppfatta som en gudsförgäten håla visar sig vara internationellt känt och uppvisar en imponerande såväl världslig som andlig rikedom.

Boken presenterar inte bara klostret i Petjenga utan också kyrkan i Boris och Gleb, kapellet i Neiden och andra platser i norr förknippade med den helige Trifon. Boken är mycket rikt illustrerad. Framför allt imponeras läsaren av ett stort antal tidiga fotografier från slutet av 1800-talet och början av 1900-talet tagna av 
Ellisif Wessel från Kirkenes. Hon framstår som en fantastisk pionjär bland kvinnliga fotografer.

Berättelser skrivna av många besökare återges i boken men kunde ha kommenterats och analyserats mera utförligt. Besökarna upplevde inte bara exotism, utan också ortodox andlighet som förknippades med naturen och med mötet med samerna. Serck-Hanssen förmedlar också sina egna intryck från gudstjänstfirande i klostret och i kapellen. Hennes egen berättelse liksom boken i sin helhet visar en författare som tar sig an sitt ämne inte bara med stora kunskaper och stort intresse utan också med stor sympati för de människor som levat och lever i detta område liksom för den ortodoxa fromheten.

Många namn och många platser behandlas i boken och jag saknar en översiktlig karta som skulle göra det klarare hur kyrkor och kloster är belägna i förhållande till varandra. Boken blir genom sitt upplägg rörig, den blandar ohämmat allt från historiska och religiösa grundfakta till detaljerade beskrivningar av människors personliga och andliga möten. Allt är i sig intressant, som redogörelsen för skoltsamernas ekonomiska förhållanden, handeln i området, kulturkontakter och den ryska geografiska och militära expansionen. Boken hinner också med att ta upp frågor om skatterätt, fiskerätt och turism.

En fråga som ställs flera gånger i boken gäller vilken verklighet som helgonlegenden avspeglar. Den gäller inte bara de tidiga helgonlegenderna om Trifon utan även den nya, författad av biskopen Mitrofan som dessutom skrivit en akademisk avhandling om den. Jag saknar i litteraturlistan och framför allt i diskussionen en av de bästa böckerna inom ämnet rysk hagiografi: bergensaren Jostein Børtnes, Visions of Glory: Studies in Early Russian Hagiography från 1988. Den kunde ha bidragit till att räta upp bokens teoretiska ansatser.

I vilken utsträckning var kulturblandningen och den etniska mångfalden positiv för skoltsamerna och för andra etniska grupper i trakten? Vi får veta att Trifon blev misshandlad av upprörda samer under sitt missionsarbete men att de ortodoxa prästerna senare accepterade samernas egna religiösa bruk lättare än de lutherska prästerna. Den ryske prästen Konstantin Sjtjekoldin och hans hustru översatte i slutet av 1800-talet Matteusevangeliet och centrala ortodoxa böner till skoltsamiska och utgav en ordbok och en grammatik, allt detta med kyrillisk skrift.

Den by som ligger närmast gränsen har uppkallats efter de två helgonen Boris och Gleb. Där byggde Trifon ett kapell, som sedan kompletterades med en kyrka och en skoltsamisk begravningsplats. 1915 anlände en professor från Kristiania och trots protester från lokalbefolkningen grävde han upp bortåt etthundra samiska skelett, som fördes bort till universitetets samlingar. Kvarlevorna har under senare tid återförts till och återbegravts på kyrkogården, en typ av kränkning av samerna som också är känd från Sverige.

Någon form av kolonial eller postkolonial teori skulle ha varit till hjälp för förståelsen av de komplexa maktrelationerna i området genom tiderna. Den annars 


\section{8 | PER-ARNE BODIN}

alltför ofta använda termen "appropriering» eller "subaltern» skulle ha kunnat vara till nytta här.

Området har varit så omstritt och så mycket våld har utvecklats här i olika konflikter. Närvaron av kyrkan i Boris och Gleb var argument vid gränsläggningen mellan Norge och Ryssland på 1800-talet. Idag är området en gräns där Nato möter Ryssland med det neutrala Finland och Sverige däremellan. Det är då trösterikt att se hur man på lokal nivå kunnat mötas och hur arvet från Trifon också kunnat förena människorna i trakten. Samma sak kan sägas om Caroline Serck-Hanssens Grenseland, som är en viktig kulturgärning och presenterar ett spännande gränsland i Norden. 